\title{
Prediksi Jenis Cacing Nematoda Usus Yang Menginfeksi Siswa Dengan Menggunakan Metoda LVQ
}

\author{
Erni Rouza \\ Program Studi Teknik Informatika Fakultas Ilmu Komputer Universitas Pasir Pengaraian \\ Jl. Tuanku Tambusai, Kumu Rambah Hilir, Pasir Pengaraian, \\ Riau, Telp. 081261445044 Kode Pos : 28557 \\ E-mail: ernirouzait@gmail.com
}

\begin{abstract}
Abstrak
Pada saat ini, Jaringan Syaraf Tiruan (JST) telah banyak menjadi objek penelitian yang menarik, karena penerapannya sangat potensial dalam berbagai bidang sains, salah satu penerapannya didalam memprediksi penyakit. Penelitian ini bertujuan untuk mencoba menerapkan metode Learning vector Quantization (LVQ) dalam memprediksi jenis cacing Nematoda usus yang menginfeksi siswa dari nilai akurasi yang dihasilkan, karena beberapa penelitian menunjukkan bahwa anak usia sekolah dasar merupakan golongan yang sering terkena infeksi cacing usus. Dari hasil pelatihan dan pengujian menggunakan metode Learning Vector Quantization (LVQ) diketahui bahwa tingkat akurasi sesuai dengan hasil sebenarnya dan nilainya konstan, proses cepat hanya membutuhkan waktu paling lama 3 menit dan memberikan hasil yang optimal yaitu tingkat akurasi data latih sebesar 78,6885\%, serta $80 \%$ untuk data uji. Hal ini menunjukkan bahwa jaringan yang terbentuk sudah cukup baik, akurat dan cepat dalam melakukan pembelajaran terhadap data input yang diberikan dalam memprediksi jenis cacing Nematoda Usus yang menginfeksi siswa.
\end{abstract}

Kata kunci : Cacing Nematoda Usus, Jaringan Syaraf Tiruan, Learning Vector Quantization

\begin{abstract}
At this time, an Artificial Neural Network (ANN) has been an interesting objects of research, because of application has potential in various fields of science, one application was used to predict diseases. This study aims to try to implement methods Learning vector quantization (LVQ) in predicting the type of Nematode worms that infect the intestines of students from the resulting accuracy value, because some studies show that children of primary school age are often exposed to a class of intestinal worm infections. From the results of the training and testing using methods Learning Vector Quantization (LVQ) note that the level of accuracy in accordance with the actual results and the value of the constant, quick process only takes a maximum of 3 minutes and provide optimal results is the level of training data accuracy of $78.6885 \%$, and $80 \%$ for the test data. This indicates that the network is formed is quite good, accurate and fast in doing the learning on the input data given in predicting Intestinal Nematode worm species that infect students.
\end{abstract}

Keywords: Intestinal Netamoda Worms, Artificial Neural Network, Learning Vector Quantization 


\section{Pendahuluan}

Cacing masih banyak menyebabkan masalah pada hewan dan manusia[1]. Bukan hanya itu hasil survei Departemen Kesehatan Republik Indonesia di beberapa provinsi di Indonesia menunjukkan bahwa bahwa sekitar 40 hingga 60 persen penduduk Indonesia terserang penyakit cacingan[3]. Meskipun demikian, penyakit cacingan ini masih sering dianggap sebagai angin lalu tidak hanya oleh masyarakat tetapi juga pemerintah. Padahal, penyakit cacingan dapat mengakibatkan menurunnya kondisi kesehatan, gizi, dan kecerdasan penderitanya sehingga dipandang sangat merugikan, karena dapat menyebabkan kehilangan karbohidrat dan protein serta kehilangan darah. Hal ini dibuktikan dengan adanya berbagai penelitian yang menunjukkan bahwa anak usia sekolah dasar merupakan golongan yang sering terkena infeksi cacing usus karena sering berhubungan dengan tanah.[4],[5].

Tanah merupakan media transmisi telur cacing golongan nematoda ke manusia dari tanah yang mengandung telur cacing yang disebut dengan "Soil Transmitted Helminthes (STH)". Telur Soil Transmitted Helminths (STH) ini dikeluarkan bersamaan dengan tinja orang yang terinfeksi. Jenis cacing Soil Transmitted Helminths (STH) antara lain ascaris lumbricoides (cacing gelang), trichuris trichiura (cacing cambuk), ancylostoma duodenale dan necator americanus (cacing tambang)[5].

Madrasah Ibtidaiyah (MI) Darul Ikhsaniah Muara Musu Kecamatan Rambah Hilir merupakan salah satu sekolah tingkat sekolah dasar yang ada di Kabupaten Rokan Hulu. Hasil dari observasi awal, sekolah tersebut memiliki lingkungan dengan kondisi kesehatan yang kurang baik, dimana tidak tersedianya sarana cuci tangan yang memadai dan halaman sekolah yang masih berupa tanah dan berlumpur pada waktu musim hujan. Pada umumnya siswa-siswi tinggal di sekitar sekolah dan belum menunjukkan aspek kebersihan yang layak. Saat dijumpai siswa di sekolah terlihat beberapa siswa tersebut badannya kurus, perut nampak buncit, kurang gizi, matanya cekung, serta pucat. Hal tersebut merupakan gejala infeksi cacingan (Surat Keputusan Menteri Kesehatan No: 424/MENKES/SK/VI/, 2006: 9). Berkaitan dengan hal tersebut, diperlukan suatu upaya bersama untuk memprediksi secara dini jenis cacing yang menginfeksi, mengobati secara tepat dan kesadaran untuk menanggulangi penyakit ini.

Jaringan Syaraf Tiruan adalah suatu sistem cerdas menyerupai otak manusia yang mempunyai kapasitas untuk belajar, mengingat, dan membuat hubungan antar data. Jaringan Syaraf Tiruan memiliki kemampuan mengenali pola yang selalu berubah-ubah berdasarkan pengalaman melalui proses pembelajaran. Pada saat ini, Jaringan Syaraf Tiruan (JST) ini telah banyak menjadi objek penelitian yang menarik, karena penerapannya sangat potensial dalam berbagai bidang sains[6],[7].

Dalam penelitian ini menggunakan metode Learning Vektor Quantization (LVQ), karena menurut Agus Nurkhozin dan kawan-kawan metode ini dikenal prosesnya cepat, dan akurat dalam melakukan pengelompokan data yang berdasarkan sifat atribut yang dimiliki oleh sekelompok besar data[8]. Metode Learning Vector Quantization banyak digunakan untuk menyelesaikan suatu masalah yang berkaitan dengan identifikasi penyakit, identifikasi suatu pola atau pengenalan suatu pola.

Berdasarkan latar belakang tersebut diperlukan suatu penelitian pendekatan baru untuk menerapkan Jaringan Syaraf Tiruan untuk prediksi jenis cacing Nematode Usus yang menginfeksi siswa dengan menggunakan metode Learning Vector Quantization, Studi Kasus Di Madrasah Ibtidayyah Darul Ikhsaniah Muara Musu Kabupaten Rokan Hulu. 


\section{Tinjauan pustaka}

\section{a. Jaringan Syaraf Tiruan}

Jaringan Syaraf Tiruan merupakan bagian dari sistem kecerdasan buatan[10]. Jaringan Syaraf Tiruan atau neural network $(\mathrm{NN})$ adalah jaringan dari sekelompok unit pemroses kecil yang dimodelkan berdasarkan jaringan saraf manusia.

Menurut Mubiru (2011), Jaringan Syaraf Tiruan adalah sebuah system cerdas yang mempunyai kapasitas untuk belajar, mengingat, dan membuat hubungan antar data[11]. Sedangkan menurut Siang (2009), Jaringan Syaraf Tiruan merupakan sistem pemproses informasi yang memiliki karakteristik mirip dengan jaringan syaraf biologi[12].

Metode neural network atau metode Jaringan Syaraf Tiruan yang akan digunakan pada penelitian ini adalah menggunakan metode Learning Vector Quantization. Metode ini hanya menggunakan alur maju saja dalam perhitungannya. Jika dua vektor mendekati sama, maka lapisan kompetitif akan meletakkan kedua vektor masukan tersebut ke dalam kelas yang sama[13].

\section{b. Komponen Jaringan Syaraf}

Jaringan Syaraf Tiruan terdiri dari beberapa komponen berikut;

1. Neuron yaitu sel syaraf yang akan mentransformasikan informasi yang diterima melalui sambungan keluarnya menuju neuron - neuron lain;

2. Bobot yaitu hubungan antar neuron;

3. Neuron Layers yaitu tempat dimana neuron-neuron akan dikumpulkan dalam lapisanlapisan (layers).

Ada beberapa tipe jaringan syaraf, namun demikian, hampir semuanya memiliki komponen-komponen yang sama. Seperti halnya otak manusia, jaringan syaraf juga terdiri-dari beberapa neuron, dan ada hubungan antara neuron-neuron tersebut. Gambar 2.1 menunjukkan struktur neuron pada jaringan syaraf [14].

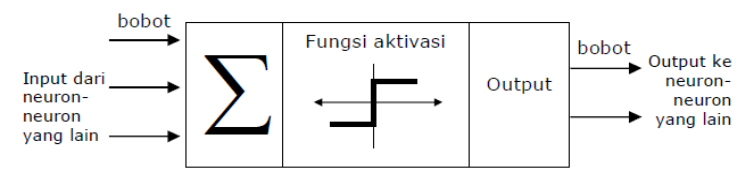

\section{Gambar.1 Struktur Neuron Jaringan Syaraf}

\section{c. Learning Vector Quantization (LVQ)}

Metode Learning Vector Quantization digunakan untuk mengelompokkan pola-pola ke dalam kelas - kelas pola. Learning Vector Quantization Termasuk Jaringan Syaraf dengan tipe arsitektur jaringan lapisan tunggal umpan-maju (Single Layer Feedforward) yang terdiri atas lapisan masukan dan lapisan keluaran.

Learning Vector Quantization merupakan suatu metode klasifikasi pola pada masingmasing unit keluaran mewakili kategori atau kelas tertentu (beberapa unit keluaran seharusnya digunakan untuk masing-masing kelas).Vektor bobot untuk suatu unit keluaran sering dinyatakan sebagai sebuah vector referns. Diasumsikan bahwa serangkaian pola pelatihan dengan klasifikasi yang tersedia bersama dengan distribusi awal vector referens. Setelah pelatihan, jaringan Learning Vector Quantization mengklasfikasi vektor masukan dengan menugaskan ke kelas yang sama sebagai unit keluaran, sedangkan yang mempunyai vector referns diklasifikasikan sebagai vektor masukan [3]. 
Gambar arsitektur jaringan Learning Vector Quantization akan dijelaskan pada gambar 2

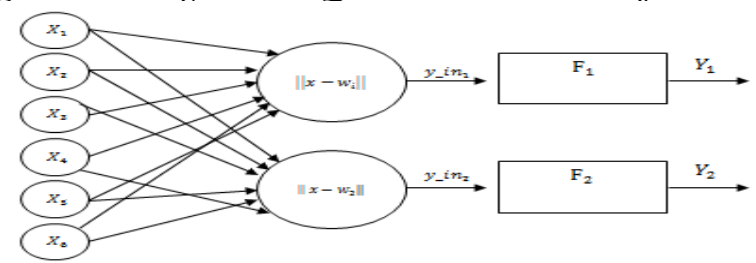

\section{Gambar.2 Arsitektur Jaringan Learning Vector Quantization}

Metode Learning Vector Quantization banyak digunakan untuk menyelesaikan suatu masalah yang berkaitan dengan identifikasi penyakit, identifikasi suatu pola atau pengenalan suatu pola. Langkah-langkah algoritma pelatihan LVQ terdiri atas[3];

1. Inisialisasi bobot $w_{j}$ dan derajat pembelajaran $\alpha(0)$.

2. Selama kondisi berhenti masih salah, kerjakan langkah 2 sampai 6.

3. Untuk setiap vektor masukan pelatihan $x$ kerjakan langkah 3 - 4 .

4. Temukan $j$ sehingga $\left|x-w_{j}\right|$ minimum.

5. Perbaharui $w_{j}$ sebagai berikut :

Jika $T=C_{j}$ maka

$w_{j}(t+1)=w_{j}(t)+\alpha(t)\left[x(t)-w_{j}(t)\right](2.5)$

Jika $T \neq C_{j}$ maka

$w_{j}(t+1)=w_{j}(t)-\alpha(t)\left[x(t)-w_{j}(t)\right](2.6)$

6. Kurangi rerata pembelajaran $\alpha$

7. Tes kondisi berhenti dengan $x$, vektor-vektor pelatihan $\left(x_{1}, \ldots x_{i}, \ldots x_{n}\right) . T$, kategori atau kelas yg benar untuk vector-vektor pelatihan $W_{j}$, vektor bobot pada unit keluaran ke-j $\left(w_{1 j}, \ldots w_{i j}, \ldots, w_{n j}\right) . C_{j}$, kategori atau kelas yang merepresentasikan oleh unit keluaran ke-j. $\left\|x-w_{j}\right\|$, jarak Euclidean antara vektor masukan dan vektor bobot untuk unit keluaran ke-j.

\section{Metode Penelitian}

Metode penelitian ini dilaksanakan dengan sistematika sebagai pedoman dalam melakukan penelitian agar hasil yang ingin dicapai tidak menyimpang dari tujuan yang telah ditetapkan sebelumnya. Kerangka kerja dalam melakukan penelitian ini dapat digambarkan seperti gambar 3 berikut:

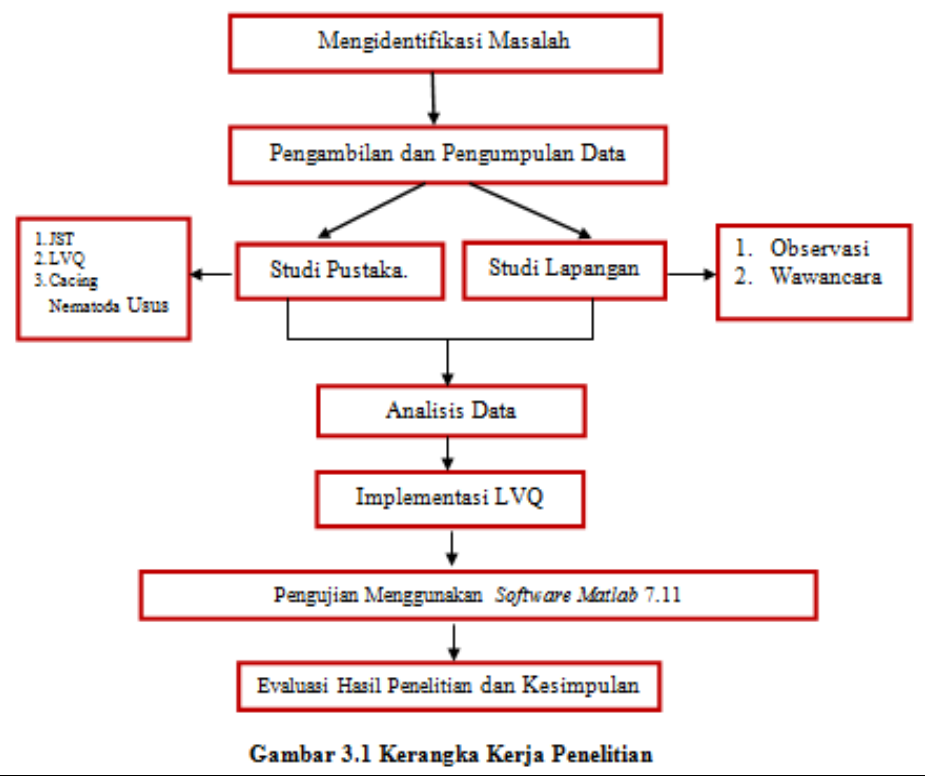


Dari kerangka kerja penelitian yang digambarkan pada gambar 3.1, dapat diuraikan pembahasan masing-masing penelitian sebagai berikut, yaitu:

1. Mengidentifikasi Masalah

Pada tahap ini penulis mengawali penelitian dengan dengan mengidentifikasi permasalahan dengan mencari topik yang akan diuji, mencari literatur yang sesuai dengan permasalahan penelitian dan proses pembuatan penelitian ini.

2. Pengambilan dan Pengumpulan Data

Data yang diambil adalah data siswa kelas 1 (satu) sampai kelas 6 (Enam) Madrasah Ibtidayyah Darul Ikhsaniah Muara Musu Kabupaten Rokan Hulu. Terdiri dari 61 siswa sebagai data pembelajaran dan 25 siswa sebagai data pengujian yang diambil secara random.

3. Penelitian ini dilakukan dengan studi kepustakaan dan studi lapangan dengan melakukan observasi langsung dan wawancara ke Madrasah Ibtidayyah Darul Ikhsaniah Muara Musu.

4. Analisis Data

Setelah pengumpulan data selesai, langkah selanjutnya adalah menganalisa data, pada penelitian ini tahap-tahap analisa data adalah sebagai berikut:

a. Menetapkan variabel-variabel input dan output yang akan digunakan. Variabel utamanya adalah jenis-jenis cacing Nematoda usus, untuk variabel input, data yang digunakan adalah berdasarkan gejala-gajala yang ditimbulkan jika terinfeksi cacing Nematoda usus, sedangkan variabel output yaitu jenis cacing Ascaris Lumbricoides (cacing gelang), Trichuris Trichiura (cacing cambuk), dan Oxyuris/ Enterobius Vermicularis (cacing kremi)

b. Menentukan nilai bobot awal, jumlah epoch (iterasi), nilai learning rate, dan nilai error minimum disesuaikan selama proses pembelajaran berlangsung.

5. Implementasi LVQ

Pada tahap ini, dilakukan pelatihan dan pengujian data dengan menggunakan Jaringan Syaraf Tiruan dengan metode Learning Vektor Quantization, dan diimplementasikan menggunakan tool Matlab 7.11, sehingga diharapkan dapat memprediksi secara dini jenis penyakit cacing Nematoda usus yang menginfeksi siswa, sehingga orang tua dapat dengan cepat mengambil tindakan dalam menanggulangi penderita cacingan serta mencegah hal-hal yang dapat menimbulkan gejala-gejala penyakit cacingan.

1. Pengujian Menggunakan Software Matlab 7.11

Pada tahapan ini, pengujian dilakukan menggunakan variabel yang diperoleh menggunakan metode Learning Vektor Quantization secara perhitungan manual, dimana data gejala-gejala yang ada pada siswa diolah berdasarkan tahapan Learning Vektor Quantization. Dimulai dari inisialisasi bobot $w_{j}$, derajat pembelajaran $\alpha(0)$ hingga didapat data keluaran atau output dan dari hasil perhitungan tersebut akan dibandingkan dengan pengujian data dalam sebuah perangkat lunak yaitu Menggunakan Software Matlab 7.11

2. Evaluasi Hasil Penelitian dan Kesimpulan

Setelah dilakukan pengujian tahap selanjutnya yaitu:

a. Tahapan evaluasi hasil penelitian, tahap ini merupakan tahapan untuk mengetahui apakah hasil training yang terbaik mempunyai hasil ketepatan atau kebenaran yang cukup baik dan pembelajaran yang cukup baik.

b. Tahap menarik kesimpulan, tahap ini untuk mengetahui apakah metode Learning Vektor Quantization ini dapat digunakan untuk melakukan prediksi jenis cacing nematoda usus yang menginfeksi siswa atau sebaliknya. 


\section{Hasil dan Pembahasan}

\section{a. Analisis Data Cacing dan Gejala}

Data yang digunakan dalam proses pembelajaran dan pengujian untuk memprediksi jenis cacing Nematoda Usus yang menginfeksi siswa Madrasah Ibtidayyah (Mi) Darul Ikhsaniah Muara Musu Kabupaten Rokan Hulu adalah data gejala-gejala yang ditimbulkan dari tiga jenis cacing Nematoda usus. Jumlah data siswa yang digunakan sebagai data masukan yaitu 61 siswa sebagai data pembelajaran dan 25 siswa sebagai data pengujian yang diambil secara random. Data-data tersebut diolah menjadi beberapa variabel yang akan menjadi data masukan. Berdasarkan gejala klinis yang terdapat pada penderita penyakit cacingan[4], dapat dikelompokkan jenis-jenis cacing Nematoda usus dan gejala yang ditimbulkan pada tabel 1 .

\section{Tabel 1. Jenis-Jenis Cacing Nematoda Usus dan Gejala Yang Ditimbulkan}

\begin{tabular}{|c|c|}
\hline Jenis Cacing Nematoda Usus & Gejala Yang Ditimbulkan \\
\hline Cacing Gelang/Ascaris Lumbricoides & $\begin{array}{l}\text { Batuk kering tidak sembuh-sembuh, } \\
\text { mual muntah, berat badan turun } \\
\text { drastis/kurus, diare, tinja berdarah, } \\
\text { demam, nafsu makan berkurang, sesak } \\
\text { nafas, perut buncit, mata pucat dan } \\
\text { kotor seperti sakit mata. }\end{array}$ \\
\hline Cacing Cambuk/ Trichuris Trichiura & $\begin{array}{l}\text { Anemia, daya tahan tubuh menurun, } \\
\text { nyeri perut bagian atas, Diare disertai } \\
\text { darah atau berlendir, mual, muntah, } \\
\text { demam disertai batuk }\end{array}$ \\
\hline $\begin{array}{c}\text { Cacing Kremi (Oxyuris/Enterobius } \\
\text { Vermicularis) }\end{array}$ & $\begin{array}{l}\text { Gatal pada anus, susah tidur rewel, } \\
\text { karena gatal pada anus, nyeri } \\
\text { perut,mual }\end{array}$ \\
\hline
\end{tabular}

\section{b. Analisis Variabel Gejala Cacingan}

Gejala pada tabel 1 merupakan kriteria yang akan menjadi acuan dalam pengambilan keputusan pada penilaian dengan menggunakan Jaringan Syaraf Tiruan. Data mentah tersebut akan disusun menjadi variabel $X_{1}$ hingga $X_{13}$ yang akan menjadi data masukan pada simulasi. Di mana variabel tersebut akan menjadi data masukan. Untuk setiap variabel akan diberikan nilai 0 atau 1 di mana nilai 0 untuk variabel Tidak sedangkan nilai 1 untuk variabel Ya. Untuk nilai dari seluruh variabel dijelaskan pada tabel 2.

Tabel 2. Inisialisasi Gejala-Gejala Cacingan Dalam Variabel $X_{n}$

\begin{tabular}{|c|c|c|c|}
\hline Variabel & Gejala & $\begin{array}{c}\text { Gejala Yang } \\
\text { Dirasakan? } \\
\text { (Ya) }\end{array}$ & $\begin{array}{c}\text { Gejala Yang } \\
\text { Dirasakan? } \\
\text { (Tidak) }\end{array}$ \\
\hline$X_{1}$ & $\begin{array}{l}\text { Batuk kering tidak } \\
\text { sembuh-sembuh }\end{array}$ & 1 & o \\
\hline$X_{2}$ & Tinja Berdarah & 1 & o \\
\hline$X_{3}$ & $\begin{array}{l}\text { Demam (batuk dan sesak } \\
\text { nafas) }\end{array}$ & 1 & o \\
\hline$X_{4}$ & Nafsu makan berkurang & 1 & O \\
\hline$X_{5}$ & $\begin{array}{l}\text { Berat badan turun } \\
\text { rastis/kurus }\end{array}$ & 1 & o \\
\hline$X_{6}$ & Mual dan muntah & 1 & o \\
\hline$X_{7}$ & Diare & 1 & o \\
\hline$X_{8}$ & Perut Buncit & 1 & o \\
\hline$X_{9}$ & $\begin{array}{l}\text { Mata Pucat dan kotor } \\
\text { seperti sakit mata. }\end{array}$ & 1 & o \\
\hline$X_{10}$ & Anemia (Kurang Darah) & 1 & o \\
\hline$X_{11}$ & Daya tahan tubuh menurun & 1 & O \\
\hline$X_{12}$ & Gatal pada anus & 1 & o \\
\hline$X_{13}$ & Susah tidur rewel & 1 & o \\
\hline
\end{tabular}




\section{c. Desain Sistem}

Setelah melakukan pengambilan data dan analisis data, langkah selanjutnya yaitu mendesain sistem, desain sistem ini berdasarkan input, proses dan output.

Data-data yang menjadi variabel masukan pada proses penerapan Learning Vector Quantization untuk prediksi jenis cacing Nematoda yang menginfeksi siswa adalah data yang terdapat pada tabel 4.2 yang terdiri dari $X_{1}$ hingga $X_{13}$. Data tersebut merupakan gejala-gejala cacingan. Selain data masukan, pada metode Learning Vector Quantization target atau kelas ditentukan terlebih dahulu, di mana kelas/target jenis penyakit cacingan terutama cacing Nematoda Usus yang dapat dilihat pada tabel 3.

Tabel 3. Kelas Cacing Nematoda Usus

\begin{tabular}{|c|c|}
\hline Satuan Nilai & Keterangan \\
\hline 1 & Ascaris Lumbricoides (cacing gelang) \\
\hline 2 & Trichuris Trichiura (cacing cambuk) \\
\hline 3 & Oxyuris/Enterobius Vermicularis (cacing kremi) \\
\hline
\end{tabular}

\section{d. Analisis Metode}

Pada langkah ini akan dilakukan analisis metode yang ada dalam penelitian. Untuk menggambarkan setiap bagian dari alur kerja digunakan suatu block diagram. Block diagram Jaringan Syaraf Tiruan Learning Vector Quantization untuk prediksi jenis cacing Nematoda yang menginfeksi siswa dapat dilihat pada gambar 4 .

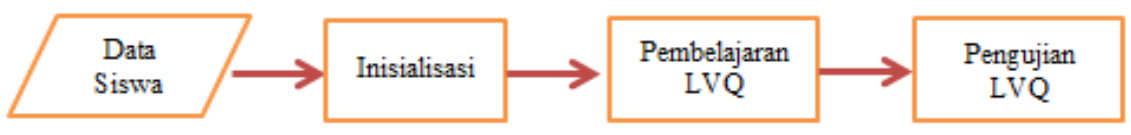

\section{Gambar 4. Block Diagram Learning Vector Quantization Untuk Memprediksi Jenis Cacing Nematoda Usus Yang Menginfeksi Siswa.}

Berdasarkan gambar 4 diatas dapat dijelaskan proses prediksi jenis cacing Nematoda usus yang menginfeksi siswa sebagai berikut;

\section{Inisialisasi}

Inisialisasi merupakan tahapan untuk menentukan nilai bobot awal, maksimum epoch atau maksimum iterasi(MaxEpoch), learning rate( $\alpha$ ), error minimum (eps), jumlah data pembelajaran, jumlah kelas dan nilai awal epoch yang dibutuhkan untuk melakukan proses pembelajaran Learning Vector Quantization. Agar dapat dikenali oleh Jaringan Syaraf Tiruan Learning Vector Quantization, data pada variabel masukan harus diubah ke dalam bentuk numerik yang biasanya disebut dengan normalisasi. Hasil dari normalisasi data akan dijadikan acuan untuk proses deteksi dengan menggunakan Learning Vector Quantization (LVQ).

Normalisasi data bertujuan menyesuaikan data latih (training) dan data uji (testing) sebelum masuk ke proses pelatihan. Setiap data dinormalisasikan terlebih dahulu, setiap variabel akan diberikan nilai 0 atau 1 di mana nilai 0 untuk variabel Tidak sedangkan nilai 1 untuk variabel Ya. Untuk data penyakit cacingan pada siswa yang dijadikan contoh 
kasus terdapat pada tabel 4. Dimana data siswa tersebut diambil secara acak sebanyak 10 data dari angket atau quisioner yang telah disebar.

Tabel 4. Contoh Data Gejala Cacingan Pada Siswa

\begin{tabular}{|c|c|c|c|c|c|c|c|c|c|c|c|}
\hline No & Data & 1 & 2 & 3 & 4 & 5 & 6 & 7 & 8 & 9 & 10 \\
\hline 1 & Batuk kering tidak sembuh-sembuh & Tidak: & Tidak & Tidak & Tidak: & Tidak & Tidak & Tidak & Tidak & Tidak & Tidak: \\
\hline 2 & Tinja Berdarah & $\mathrm{Ya}$ & Tidal: & Tidak & Tidak & Tidak & Tidak & Tidak & Tidak & Tidal: & Tidak: \\
\hline 3 & Demam (batuk dan sesak nafas) & Tidak & Tidak: & Tidak & Tidak & $\mathrm{Ya}$ & Tidak & Ya & $\mathrm{Ya}$ & $\mathrm{Ya}$ & Tidak \\
\hline 4 & Nafsu makan berkurang & $\mathrm{Ya}$ & Tidal: & Tidak & $\mathrm{Ya}$ & $\mathrm{Ya}$ & $\mathrm{Ya}$ & $\mathrm{Ya}$ & $\mathrm{Ya}$ & Tidak & Tidak \\
\hline 5 & Berat badan turun rastis/kurus & Tidak & Tidal: & Tidak & $\mathrm{Ya}$ & Tidak & $\mathrm{Ya}$ & $\mathrm{Ya}$ & $\mathrm{Ya}$ & Tidak & Tidal: \\
\hline 6 & Mual dan muntah & Tidak: & Tidak & Tidak & $\mathrm{Ya}$ & $\mathrm{Ya}$ & Tidak & Tidak & Tidak & Tidak & Tidak: \\
\hline 7 & Diare & $\mathrm{Ya}$ & $\mathrm{Ya}$ & Tidak & $\mathrm{Ya}$ & Tidak & Tidak & Tidak: & $\mathrm{Ya}$ & Tidak & Tidal: \\
\hline 8 & Perut Buncit & Tidak & Tidak & Tidak & Tidak & Tidak & $\mathrm{Ya}$ & Tidak & Tidak & $\mathrm{Ya}$ & Tidak \\
\hline 9 & $\begin{array}{l}\text { Mata Pucat dan kotor seperti sakit } \\
\text { mata. }\end{array}$ & Tidalk & Tidak & $\mathrm{Ya}$ & Tidak & Tidak: & Tidal: & Tidak & Tidak & Tidak & Tidal: \\
\hline 10 & Anemia (Kurang Darah) & Tidak & $\mathrm{Ya}$ & $\mathrm{Ya}$ & $\mathrm{Ya}$ & Tidak: & Tidak & Tidak & Tidak & $\mathrm{Ya}_{\mathrm{a}}$ & Tidak: \\
\hline 11 & $\begin{array}{l}\text { Daya tahan tubuh menurun, sering } \\
\text { sakit }\end{array}$ & Tidak & $\mathrm{Ya}$ & $\mathrm{Ya}$ & Tidak & Tidak & Tidak & Tidak & Tidak & $\mathrm{Ya}$ & Tidak \\
\hline 12 & Gatal pada anus & Tidalk & Tidak & $\mathrm{Ya}_{\mathrm{a}}$ & Tidal: & Tidal: & Tidalk & Tidak & Tidak & $\mathrm{Ya}_{\mathrm{a}}$ & $\mathrm{Ya}_{\mathrm{a}}$ \\
\hline 13 & Susah tidur rewel & Tidal: & Tidal: & $\mathrm{Ya}$ & Tidal: & Tidal: & Tidal: & Tidal: & Tidal: & Tidal: & $\mathrm{Ya}$ \\
\hline
\end{tabular}

Proses normalisasi data gejala cacingan yang ada pada tabel 4 terdapat pada tabel 5 . Hasil dari normalisasi tersebut yang akan dimasukkan ke dalam proses Learning Vector Quantization untuk memprediksi jenis-jenis cacing Nematoda usus yang menginfeksi siswa Madrasah Ibtidaiyah (MI) Darul Ikhsaniah Muara Musu Kecamatan Rambah Hilir Kabupaten Rokan Hulu.

Tabel 5. Hasil Normalisasi Variabel Gejala Cacingan Pada Siswa

\begin{tabular}{|c|c|c|c|c|c|c|c|c|c|c|}
\hline $\begin{array}{c}\text { Data/ } \\
\mathbf{W}\end{array}$ & $\mathbf{1}$ & $\mathbf{2}$ & $\mathbf{3}$ & $\mathbf{4}$ & $\mathbf{5}$ & $\mathbf{6}$ & $\mathbf{7}$ & $\mathbf{8}$ & $\mathbf{9}$ & $\mathbf{1 0}$ \\
\hline $\mathbf{X}_{\mathbf{1}}$ & 0 & 0 & 0 & 0 & 0 & 0 & 0 & 0 & 0 & 0 \\
\hline $\mathbf{X}_{\mathbf{2}}$ & 1 & 0 & 0 & 0 & 0 & 0 & 0 & 0 & 0 & 0 \\
\hline $\mathbf{X}_{\mathbf{3}}$ & 0 & 0 & 0 & 0 & 1 & 0 & 1 & 1 & 1 & 0 \\
\hline $\mathbf{X}_{\mathbf{4}}$ & 1 & 0 & 0 & 1 & 1 & 1 & 1 & 1 & 0 & 0 \\
\hline $\mathbf{X}_{\mathbf{5}}$ & 0 & 0 & 0 & 1 & 0 & 1 & 1 & 1 & 0 & 0 \\
\hline $\mathbf{X}_{6}$ & 0 & 0 & 0 & 1 & 1 & 0 & 0 & 0 & 0 & 0 \\
\hline $\mathbf{X}_{7}$ & 1 & 1 & 0 & 1 & 0 & 0 & 0 & 1 & 0 & 0 \\
\hline $\mathbf{X}_{\mathbf{8}}$ & 0 & 0 & 0 & 0 & 0 & 1 & 0 & 0 & 1 & 0 \\
\hline $\mathbf{X}_{9}$ & 0 & 0 & 1 & 0 & 0 & 0 & 0 & 0 & 0 & 0 \\
\hline $\mathbf{X}_{10}$ & 0 & 1 & 1 & 1 & 0 & 0 & 0 & 0 & 1 & 0 \\
\hline $\mathbf{X}_{11}$ & 0 & 1 & 1 & 0 & 0 & 0 & 0 & 0 & 1 & 0 \\
\hline $\mathbf{X}_{12}$ & 0 & 0 & 1 & 0 & 0 & 0 & 0 & 0 & 1 & 1 \\
\hline $\mathbf{X}_{13}$ & 0 & 0 & 1 & 0 & 0 & 0 & 0 & 0 & 0 & 1 \\
\hline
\end{tabular}

Tabel 5 akan djadikan sebagai inisialisasi bobot (vektor $w$ yaitu data ke 1, data ke 2, dan data ke 3) dan data latih (vektor $x$ yaitu data ke 4, data ke 5, data ke 6, data ke 7, data ke 8 , data ke 9, dan data ke 10) dalam ke 3 kelas atau target yaitu kelas 1, 2 dan 3 seperti yang terdapat pada tabel 6 .

Tabel 6. Normalisasi Data Gejala Cacingan Pada Siswa Dengan Kelas/Target

\begin{tabular}{|c|c|c|c|c|c|c|c|c|c|c|}
\hline $\begin{array}{c}\text { Data/ } \\
\mathbf{W}\end{array}$ & $\mathbf{1}$ & $\mathbf{2}$ & $\mathbf{3}$ & $\mathbf{4}$ & $\mathbf{5}$ & $\mathbf{6}$ & $\mathbf{7}$ & $\mathbf{8}$ & $\mathbf{9}$ & $\mathbf{1 0}$ \\
\hline $\mathbf{X}_{1}$ & 0 & 0 & 0 & 0 & 0 & 0 & 0 & 0 & 0 & 0 \\
\hline $\mathbf{X}_{\mathbf{2}}$ & 1 & 0 & 0 & 0 & 0 & 0 & 0 & 0 & 0 & 0 \\
\hline $\mathbf{X}_{3}$ & 0 & 0 & 0 & 0 & 1 & 0 & 1 & 1 & 1 & 0 \\
\hline $\mathbf{X}_{4}$ & 1 & 0 & 0 & 1 & 1 & 1 & 1 & 1 & 0 & 0 \\
\hline $\mathbf{X}_{\boldsymbol{s}}$ & 0 & 0 & 0 & 1 & 0 & 1 & 1 & 1 & 0 & 0 \\
\hline $\mathbf{X}_{6}$ & 0 & 0 & 0 & 1 & 1 & 0 & 0 & 0 & 0 & 0 \\
\hline $\mathbf{X}_{7}$ & 1 & 1 & 0 & 1 & 0 & 0 & 0 & 1 & 0 & 0 \\
\hline $\mathbf{X}_{3}$ & 0 & 0 & 0 & 0 & 0 & 1 & 0 & 0 & 1 & 0 \\
\hline $\mathbf{X}_{9}$ & 0 & 0 & 1 & 0 & 0 & 0 & 0 & 0 & 0 & 0 \\
\hline $\mathbf{X}_{10}$ & 0 & 1 & 1 & 1 & 0 & 0 & 0 & 0 & 1 & 0 \\
\hline $\mathbf{X}_{11}$ & 0 & 1 & 1 & 0 & 0 & 0 & 0 & 0 & 1 & 0 \\
\hline $\mathbf{X}_{12}$ & 0 & 0 & 1 & 0 & 0 & 0 & 0 & 0 & 1 & 1 \\
\hline $\mathbf{X}_{13}$ & 0 & 0 & 1 & 0 & 0 & 0 & 0 & 0 & 0 & 1 \\
\hline $\mathbf{K}_{\text {elas }}$ & 1 & 2 & 3 & 1 & 1 & 1 & 1 & 1 & 2 & 3 \\
\hline
\end{tabular}


Setelah proses normalisasi data gejala cacingan pada siswa dengan kelas atau target selesai, maka langkah selanjutnya adalah proses pembelajaran Learning Vector Quantization.

\section{Perancangan Jaringan Syaraf Tiruan Learning Vector Quantization}

Perancangan arsitektur Learning Vector Quantization terdiri dari lapisan input (input layer), lapisan kompetitif (terjadi kompetisi pada input untuk masuk ke dalam suatu kelas berdasarkan kedekatan jaraknya) dan lapisan output (output layer). Lapisan input dihubungkan dengan lapisan kompetitif oleh bobot. Fungsi aktivasi $(F)$ yang digunakan pada arsitektur jaringan Learning Vector Quantization untuk prediksi jenis cacing Nematoda usus yang menginfeksi siswa adalah fungsi linier. Sehingga hasil keluaran sama dengan masukan, sesuai dengan rumus fungsi linier yaitu $y=x$. Arsitektur Jaringan Syaraf Tiruan Learning Vector Quantization dapat dilihat pada gambar 5.

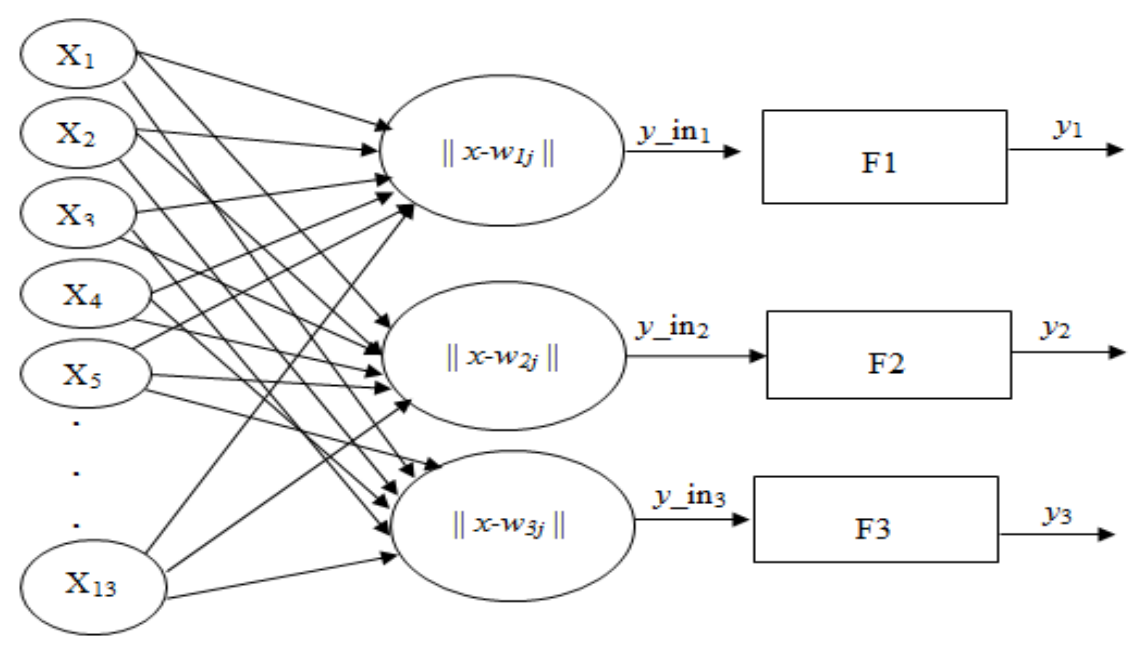

Gambar 5. Arsitektur Jaringan Learning Vector Quantization untuk Prediksi Jenis Cacing Nematoda Usus Yang Menginfeksi Siswa

Jumlah variabel input yang terdapat pada gambar di atas sebanyak 13 variabel, yaitu variabel $x_{1}$ sampai $x_{13}$, variabel yang ada pada kasus tersebut dihitung jarak bobot $w_{1 j}$, $w_{2 j}$ dan $w_{3 j}$, sehingga menghasilkan keluaran berupa $y_{1}, y_{2}$, dan $y_{3}$.

\section{Pembelajaran Learning Vector Quantization}

Flowchart proses pembelajaran Learning Vector Quantization akan digambarkan pada Gambar 6. 


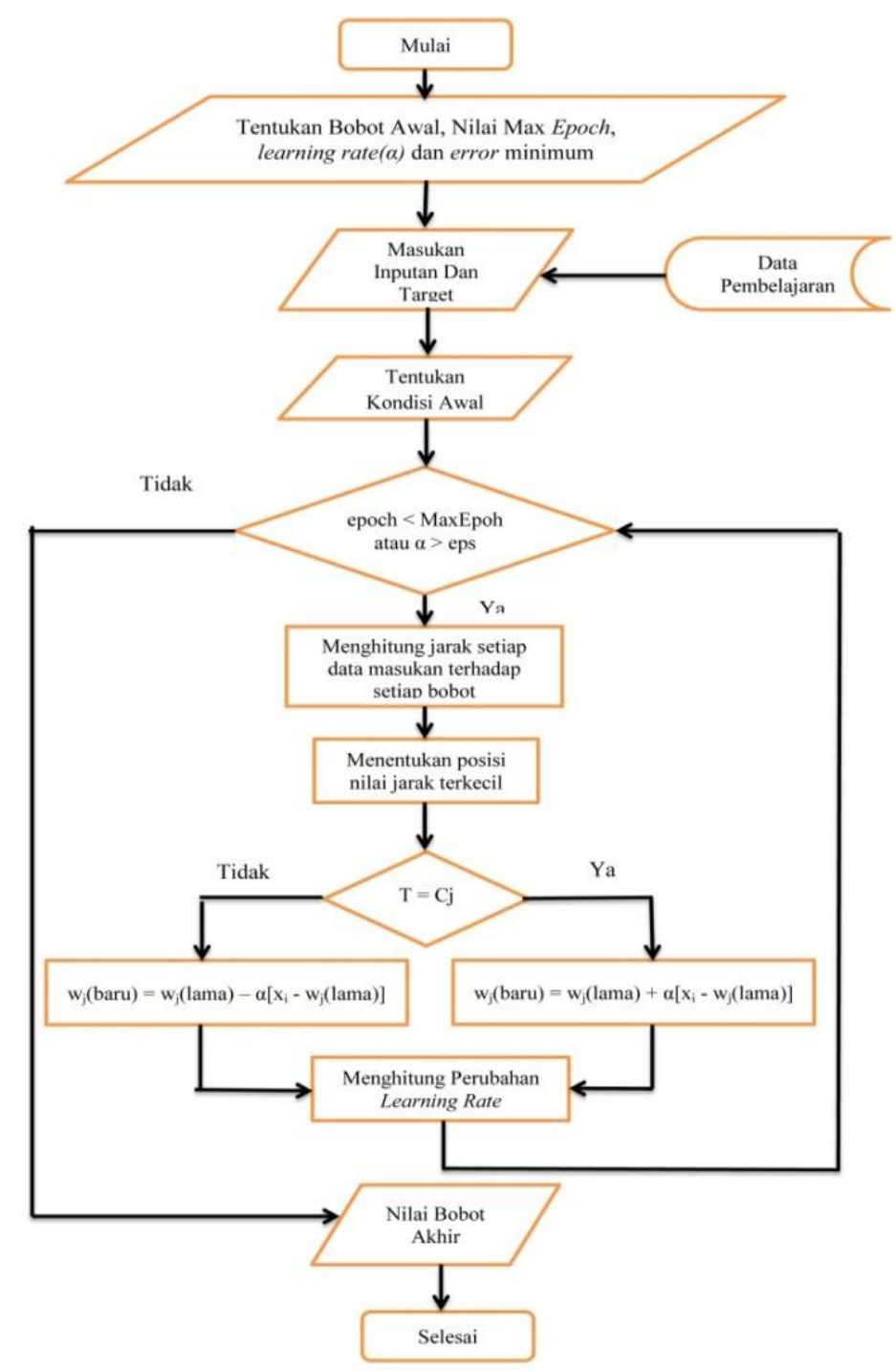

Gambar 6. Flowchart Pembelajaran Learning Vector Quantization

\section{Perancangan Perhitungan Manual Prediksi Jenis Cacing Nematoda Usus yang Menginfeksi Siswa Dengan Menggunakan Metode Learning Vektor Quantization.}

Proses prediksi dengan menggunakan Learning Vector Quantization (LVQ), dengan menggunakan hasil normalisasi pada tabel 6 yang akan menjadi acuan. Tahapan awal dalam prediksi jenis cacing Nematoda usus yang menginfeksi siswa ini, adalah menetapkan data yang dijadikan inisialisasi bobot yaitu data ke 1, data ke 2, dan data ke 3, data latih yaitu data ke 3, data ke 4, data ke 5, data ke 6, data ke 7 dan data ke 8 , data ke 9 data ke 10 . Sedangkan untuk inisialisasi nilai MaxEpoch $=0$, learning rate $(\alpha)=0,05$, eps $=0,01$, dan pengurangan sebesar $0,1 * \alpha$. 
Tabel 7. Inisialisasi Bobot dan Kelas/ Target

$\left.\begin{array}{|c|c|c|c|c|c|c|c|c|c|c|c|c|c|c|}\hline \text { N0 } & \multicolumn{10}{|c|}{\text { DATA }} & \text { Target } \\ \hline 1 & 0 & 1 & 0 & 1 & 0 & 0 & 1 & 0 & 0 & 0 & 0 & 0 & 0 & 1 \\ \hline 2 & 0 & 0 & 0 & 0 & 0 & 0 & 1 & 0 & 0 & 1 & 1 & 0 & 0 & 2 \\ \hline 3 & 0 & 0 & 0 & 0 & 0 & 0 & 0 & 0 & 1 & 1 & 1 & 1 & 1 & 3 \\ \hline\end{array}\right]$ Inisialisasi

Tabel 8. Data Latih dan Kelas/ Target

\begin{tabular}{|c|c|c|c|c|c|c|c|c|c|c|c|c|c|c|}
\hline NO & \multicolumn{10}{|c|}{ DATA (X) } & Target \\
\hline 1 & 0 & 0 & 0 & 1 & 1 & 1 & 1 & 0 & 0 & 1 & 0 & 0 & 0 & 1 \\
\hline 2 & 0 & 0 & 1 & 1 & 0 & 1 & 0 & 0 & 0 & 0 & 0 & 0 & 0 & 1 \\
\hline 3 & 0 & 0 & 0 & 1 & 1 & 0 & 0 & 1 & 0 & 0 & 0 & 0 & 0 & 1 \\
\hline 4 & 0 & 0 & 1 & 1 & 1 & 0 & 0 & 0 & 0 & 0 & 0 & 0 & 0 & 1 \\
\hline 5 & 0 & 0 & 1 & 1 & 1 & 0 & 1 & 0 & 0 & 0 & 0 & 0 & 0 & 1 \\
\hline 6 & 0 & 0 & 1 & 0 & 0 & 0 & 0 & 1 & 0 & 1 & 1 & 1 & 0 & 2 \\
\hline 7 & 0 & 0 & 0 & 0 & 0 & 0 & 0 & 0 & 0 & 0 & 0 & 1 & 1 & 3 \\
\hline
\end{tabular}

Hasil perhitungan secara manual untuk mendapatkan bobot terakhir data latih ke-7 dari data siswa yang terinfeksi jenis cacing Nematoda usus sebagai berikut:

Tabel 9. Nilai Bobot Baru $w_{1}, w_{2}$, Dan $w_{3}$

\begin{tabular}{|c|c|c|c|c|c|c|c|c|c|c|c|c|c|}
\hline Bobot Baru Ke & $w j, 1$ & $w j, 2$ & $w j, 3$ & $w j, 4$ & $w j, 5$ & $w j, 6$ & $w j, 7$ & $w j, 8$ & $w j, 9$ & $w j, 10$ & $w j, 11$ & $w j, 12$ & $w j, 13$ \\
\hline$w 1$ & 0 & 0,7738 & 0,1404 & 1 & 0,18335 & 0,083594 & 0,864506 & 0,0451 & 0 & 0,041 & 0 & 0 & 0 \\
\hline$w 2$ & 0 & 0 & 0,05 & 0 & 0 & 0 & 0,95 & 0,05 & 0 & 1 & 1 & 0,05 & 0 \\
\hline$w 3$ & 0 & 0 & 0 & 0 & 0 & 0 & 0 & 0 & 0,95 & 0,95 & 0,95 & 1 & 1 \\
\hline
\end{tabular}

Sebelum masuk ke epoch ke-2 hingga epoch maksimum, learning rate $(\alpha)$ di update terlebih dahulu dengan rumus $\alpha=\alpha-0,1^{*} \alpha$ (lama), sehingga didapat learning rate untuk epoch ke-2 yaitu: $\alpha=0,05-0,1 * 0,05=0,045$. Untuk hasil nilai bobot $w_{1}, w_{2}$, w3 pada epoch selanjutnya dihitung menggunakan Matlab 7.11, adapun hasil epoch ke-10 adalah sebagai berikut:

Tabel 10. Nilai Bobot Baru $w_{1}, w_{2}$, Dan $w_{3}$

\begin{tabular}{|c|c|c|c|c|c|c|c|c|c|c|c|c|c|}
\hline Bobot Baru Ke & $w j, 1$ & $w j, 2$ & $w j, 3$ & $w j, 4$ & $w j, 5$ & $w j, 6$ & $w j, 7$ & $w j, 8$ & $w j, 9$ & $w j, 10$ & $w j, 11$ & $w j, 12$ & $w j, 13$ \\
\hline$w 1$ & 0 & 0,1905 & 0,4959 & 1 & 0,65 & 0,3085 & 0,513 & 0,162 & 0 & 0,152 & 0 & 0 & 0 \\
\hline$w 2$ & 0 & 0 & 0,2822 & 0 & 0 & 0 & 0,7178 & 0,2822 & 0 & 1 & 1 & 0,2822 & 0 \\
\hline$w 3$ & 0 & 0 & 0 & 0 & 0 & 0 & 0 & 0 & 0,718 & 0,718 & 0,718 & 1 & 1 \\
\hline
\end{tabular}

\section{Perancangan Pengujian Learning Vector Quantization}

Setelah dilakukan tahapan pembelajaran, tahapan selanjutnya yaitu tahapan pengujian Learning Vector Quantization yang mana dari pengujian ini akan menghasilkan nilai kelas yang dikenali. Langkah-langkah pada tahapan pengujian Learning Vector Quantization dapat digambarkan dengan flowchart seperti berikut ini: 


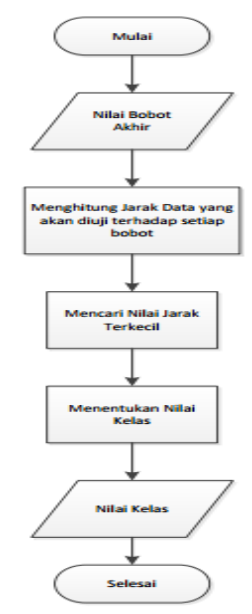

Gambar 7. Flowchart Pengujian Learning Vector Quantization

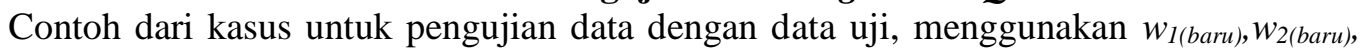
dan $w_{3 \text { (baru) }}$ hasil dari epoch ke-1 yaitu:

1. Data Uji ke-1 : $(0,0,0,0,0,0,0,0,0,1,1,0,0)$

Jarak terhadap:

1. Bobot ke- 1

$$
\begin{gathered}
\text { Jarak }=\sqrt{\begin{array}{c}
(0-0)^{2}+(0-0,774)^{2}+(0-0,14)^{2}+(0-1)^{2}+ \\
(1-0,183)^{2}+(0-0,1)^{2}+(0-0,86)^{2}+ \\
(0-0,045)^{2}+(0-0)^{2}+(1-0,04)^{2}+ \\
(1-0)^{2}+(0-0)^{2}+(0-0)^{2}
\end{array}} \\
=\sqrt{\begin{array}{c}
0+0,599+0,0197+1+0,034+0,007+0,7474 \\
0,002+0+0,92021+1+0+0
\end{array}} \\
=\sqrt{4,328661}=2,08054
\end{gathered}
$$

Hitung hingga bobot ke 3, sehingga diperoleh jarak terkecil dari pengujian tersebut ada pada bobot ke-2, sehingga data masukan tersebut termasuk ke dalam kelas 2, yaitu kelas Trichuris Trichiura (cacing cambuk) karena posisi nilai jarak terkecilnya terdapat pada bobot ke -2. Untuk nilai bobot baru terdapat pada tabel 11.

Tabel 11. Nilai Bobot Baru kelas ke-2

\begin{tabular}{|c|c|c|c|c|c|c|c|c|c|c|c|c|c|}
\hline Bobot Baru Ke & $w j, 1$ & $w j, 2$ & $w j, 3$ & $w j, 4$ & $w j, 5$ & $w j, 6$ & $w j, 7$ & $w j, 8$ & $w j, 9$ & $w j, 10$ & $w j, 11$ & $w j, 12$ & $w j, 13$ \\
\hline $\mathrm{w}$ & 0 & 0 & 0,05 & 0 & 0 & 0 & 0,95 & 0,05 & 0 & 1 & 1 & 0,05 & 0 \\
\hline$\alpha$ & 0,05 & 0,05 & 0,05 & 0,05 & 0,05 & 0,05 & 0,05 & 0,05 & 0,05 & 0,05 & 0,05 & 0,05 & 0,05 \\
\hline $\mathrm{x}$ & 0 & 0 & 0 & 0 & 0 & 0 & 0 & 0 & 0 & 1 & 1 & 0 & 0 \\
\hline $\mathrm{w}$ & 0 & 0 & 0,05 & 0 & 0 & 0 & 0,95 & 0,05 & 0 & 1 & 1 & 0,05 & 0 \\
\hline$(\mathrm{x}-\mathrm{w})$ & 0 & 0 & $-0,05$ & 0 & 0 & 0 & $-0,95$ & $-0,05$ & 0 & 0 & 0 & $-0,05$ & 0 \\
\hline $\mathrm{w}+\alpha^{*}(\mathrm{x}-\mathrm{w})$ & 0 & 0 & 0,0475 & 0 & 0 & 0 & 0,9025 & 0,048 & 0 & 1 & 1 & 0,0475 & 0 \\
\hline
\end{tabular}

Sedangkan untuk hasil nilai bobot $w_{1}, w_{2}, w_{3}$ adalah:

Tabel 12. Nilai Bobot Baru $w_{1}, w_{2}$, Dan $w_{3}$

\begin{tabular}{|c|c|c|c|c|c|c|c|c|c|c|c|c|c|}
\hline Bobot Baru Ke & $w j, 1$ & $w j, 2$ & $w j, 3$ & $w j, 4$ & $w j, 5$ & $w j, 6$ & $w j, 7$ & $w j, 8$ & $w j, 9$ & $w j, 10$ & $w j, 11$ & $w j, 12$ & $w j, 13$ \\
\hline$w 1$ & 0 & 0,7738 & 0,1404 & 1 & 0,183 & 0,1 & 0,86 & 0,0451 & 0 & 0,04 & 0 & 0 & 0 \\
\hline$w 2$ & 0 & 0 & 0,0475 & 0 & 0 & 0 & 0,9 & 0,0475 & 0 & 1 & 1 & 0,0475 & 0 \\
\hline$w 3$ & 0 & 0 & 0 & 0 & 0 & 0 & 0 & 0 & 0,95 & 0,95 & 0,95 & 1 & 1 \\
\hline
\end{tabular}

Berdasarkan tabel 11 dan tabel 12 membuktikan bahwa benar dengan data yang di input-kan sesuai dengan target yang menjadi tujuan atau sesuai dengan kenyataan. 


\section{Implementasi}

\section{a. Implementasi Sistem}

Proses komputasi jaringan yang dilakukan pada penelitian ini menggunakan program Matlab 7.11. Matlab merupakan perangkat lunak yang cocok dipakai sebagai alat komputasi yang melibatkan penggunaan matrik dan vektor. Fungi-fungsi yang digunakan dalam paket perangkat lunak (toolbox) memudahkan perhitungan dan pengujian tersebut. Banyak model Jaringan Syaraf Tiruan menggunakan manipulasi matrik atau vektor dalam iterasinya.

\section{b. Implementasi Arsitektur Learning Vector Quantization (LVQ) Dengan Matlab 7.11}

Arsitektur Learning Vector Quantization terdiri dari lapisan input (input layer), lapisan kompetitif (terjadi kompetisi pada input untuk masuk ke dalam suatu kelas berdasarkan kedekatan jaraknya) dan lapisan output (output layer). Lapisan input dihubungkan dengan lapisan kompetitif oleh bobot. Berikut ini hasil implementasi arsitektur jaringan Learning Vector Quantization dalam memprediksi data siswa yang terinfeksi cacing Nematoda Usus.

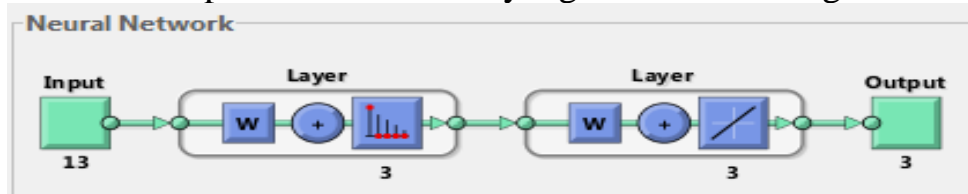

\section{Gambar 8. Arsitektur Jaringan LVQ prediksi Jenis Cacing Nematoda Usus Yang Menginfeksi Siswa}

Berdasarkan Gambar 8, terlihat bahwa arsitektur jaringan Learning Vector Quantization memiliki 13 input layer dengan 3 lapisan kompotitif, 3 hidden layer dan output yang terdiri dari 3 kelas. Fungsi aktivasi (F) yang digunakan pada arsitektur jaringan Learning Vector Quantization (LVQ) adalah fungsi linier. Tujuannya adalah agar diperoleh keluaran yang sama dengan masukan, sesuai dengan rumus fungsi linier yaitu $\mathrm{y}=\mathrm{x}$.

Pada prinsipnya metode LVQ ini akan melakukan pengenalan terlebih dahulu terhadap pola masukan yang harus disajikan dalam bentuk vektor sehingga dapat dicari kelasnya. Karena setiap neuron output menyatakan kelas atau kategori tertentu, maka pola input dapat dikenali kelasnya berdasarkan neuron keluaran yang diperoleh. Metode LVQ mengenali pola masukan berdasarkan pada kedekatan jarak antara dua vektor yaitu vektor dari unit/neuron masukan dengan vektor bobot. Pengenalan dalam metode LVQ ini terdapat dua proses, yaitu proses pembelajaran dan proses pengujian.

\section{c. Pengujian Learning Vector Quantization (LVQ) Dengan Matlab 7.11}

Pelatihan dan pengujian dengan menggunakan tools Matlab 7.11 dilakukan dengan 3 cara:

1. Pelatihan untuk menghitung bobot $w_{1}, w_{2}$ dan $w_{3}$

2. Pelatihan dan pengujian pada iterasi ke 100

3. Pengujian perbandingan akurasi tiap epoch atau iterasi.

Sehingga untuk perbandingan hasil pelatihan dan pengujian data dengan menggunakan Learning Vector Quantization berdasarkan pola 70\%:30\%, 60\%: 40\% dan 50\%:50\% dari 86 jumlah data gejala siswa yang terinfeksi cacingan dapat dilihat pada tabel 11 .

Tabel 11. Perbandingan Akurasi Klasifikasi Berdasarkan Jumlah Data

\begin{tabular}{|c|c|c|c|c|c|c|c|c|c|c|}
\hline \multirow{3}{*}{ Jumlah Data } & \multicolumn{2}{|c|}{ Pola Pembagian Data } & \multicolumn{2}{|c|}{ Jumlah Data } & \multicolumn{2}{c|}{ Jumlah Benar } & \multicolumn{2}{c|}{ Tingkat Akurasi } & \multicolumn{2}{c|}{ Tingkat Error } \\
\cline { 2 - 10 } & Data Latih & Data Uji & Data Latih & Data Uji & Data Latih & Data Uji & Data Latih & Data Uji & Data Latih & Data Uji \\
\hline \hline \multirow{3}{*}{86} & $70 \%$ & $30 \%$ & 61 & 25 & 48 & 20 & $78,69 \%$ & $80 \%$ & $21,31 \%$ & $20 \%$ \\
\cline { 2 - 11 } & $60 \%$ & $40 \%$ & 52 & 34 & 41 & 27 & $78,85 \%$ & $79,41 \%$ & $21,15 \%$ & $20,59 \%$ \\
\cline { 2 - 10 } & $50 \%$ & $50 \%$ & 43 & 43 & 33 & 36 & $76,74 \%$ & $83,72 \%$ & $23,26 \%$ & $13,95 \%$ \\
\hline
\end{tabular}


Pada tabel 11 diatas, hasil perbandingan persentase yang paling optimal yaitu pada pengujian data 50\%: 50\% dengan hasil persentase data sebesar $1.6 \%$. Sehingga pada penelitian ini menggunakan perbandingan data 50\% : 50\% untuk mengoptimalkan hasil prediksi jenis cacing Nematoda Usus yang menginfeksi siswa. Maka disimpulkan bahwa, pada pelatihan dan pengujian data siswa yang terinfeksi jenis cacing Nematoda usus ini, tidak mempengaruhi tingkat akurasi data yang signifikan dengan jumlah epoch atau iterasi, dan learning rate yang telah ditentukan. Dari pelatihan dan pengujian ini didapat tingkat akurasi data yang konstan, proses cepat hanya membutuhkan waktu paling lama 2 menit 40 detik dan memberikan hasil yang optimal yaitu tingkat akurasi data latih sebesar 76,7442\%, serta 83,7209\% untuk data uji.

Hal ini menunjukkan bahwa jaringan yang terbentuk sudah cukup baik, akurat dan cepat dalam melakukan pembelajaran terhadap data input yang diberikan dalam memprediksi jenis cacing Nematoda Usus yang menginfeksi siswa Madrasah Ibtidaiyah (MI) Darul Ikhsaniah Muara Musu Kecamatan Rambah Hilir Kabupaten Rokan Hulu.

\section{Kesimpulan}

Berdasarkan uraian-uraian yang ada pada bab-bab sebelumnya dan berdasarkan hasil penerapan, baik secara pelatihan dan pengujian, maka dapat ditarik beberapa kesimpulan:

1. Jaringan Syaraf Tiruan dengan metode Learning Vector Quantization dapat digunakan untuk memprediksi jenis cacing Nematoda usus yang menginfeksi siswa Madrasah Ibtidaiyah (MI) Darul Ikhsaniah Muara Musu Kecamatan Rambah Hilir Kabupaten Rokan Hulu.

2. Jaringan LVQ yang terdiri dari layer input, layer kompetitif dan layer output dapat digunakan untuk pengenalan pola/klasifikasi berdasarkan kedakatan jarak antar kelompok. Hasil uji coba dengan data gejala cacingan pada siswa memberikan hasil yang baik, optimal, cepat dan akurat, di mana jaringan mampu mengenali pola dengan benar, untuk data latih sebesar 76,7442\%, sedangkan untuk data uji sebesar 83,7209\%.

3. Hasil pengujian data yang telah dilatih menunjukkan performance yang cukup baik. Selisih antara target yang sebenarnya dengan hasil output program tidak menunjukkan perbedaan yang begitu besar.

4. Metode Learning Vektor Quantization ini dapat digunakan untuk melakukan prediksi jenis cacing nematoda usus yang menginfeksi siswa Madrasah Ibtidaiyah (MI) Darul Ikhsaniah Muara Musu Kecamatan Rambah Hilir Kabupaten Rokan Hulu.

Dari kesimpulan dan hasil dari penelitian yang telah dilakukan maka dapat dikemukakan beberapa saran yang diharapkan nantinya dapat menjadi bahan pertimbangan lebih lanjut dalam peningkatan untuk memprediksi jenis cacing Nematoda usus yang menginfeksi siswa, sehingga saran yang dapat penulis kemukakan untuk penelitian selanjutnya yaitu:

1. Pada penelitian selanjutnya data pelatihan dan pengujian diperbanyak jumlahnya, tambahkan data klinis yaitu dengan menemukan dan menghitung jumlah telur-telur cacing di dalam tinja serta tambahkan data ukuran cacing tersebut. Sehingga diperoleh pendiagnosaan yang tepat dengan tingkat akurasi yang lebih tinggi.

2. Penelitian selanjutnya diharapkan dapat dikembangkan dengan aplikasi yang menggunakan bahasa pemograman tertentu, sehingga pihak masyarakat atau user dapat memprediksi penyakit cacingan dengan cepat dan tepat dalam memberikan obat kepada anak yang terkena infeksi cacing.

3. Prediksi jenis cacing Nematoda usus yang menginfeksi siswa ini dapat dikembangkan dengan menggunakan GUI (Graphic User Interface) berupa pengolahan citra, sehingga dapat mempermudah pengimplementasi Jaringan Syaraf Tiruan Learning Vector Quantization oleh pengguna atau user. 


\section{Daftar Pustaka}

[1] Salhan, M., Kumar. B., Tiwari, P., Sharma, P,. Sandhar, H.K., and Gautam, M. "Comparative Anthelmintic Activity of Aqueous and Ethanolic Leaf Extracts Of Clitoria Ternatea". International Journal of Drug Development \& Research (IJDDR), 2011; Vol. 3, Issue 1,62-69. ISSN 0975-9344,

[2] Pipit Hesti. Hubungan antara penyakit cacingan dengan status gizi pada anak Sekolah Dasar (SD) di Sekolah Dasar Al Mustofa Surabaya.

[3] Depkes, RI.2006. Pedoman Pengendalian Kecacingan. Depkes RI. Jakarta.

[4] Atika Ghassani. Hubungan Infeksi Cacing Usus STH Dengan Kebiasaan Bermain Tanah Pada SDN 09 Pagi Paseban Tahun 2010.Jakarta, Universitas Indonesia; 2011.

[5] B Siregar. Beberapa Faktor Yang Berhubungan Dengan Infeksi Kecacingan Yang Ditularkan Melalui Tanah Pada Murid SD N 06 Kecamatan Pinggir Kabupaten Bengkalis. Universitas Sumatra Utara;2008.

[6] Chen Li Liu, X.. and Fu, X. Globally Exponential Stability of Impulsive Neural Networks with Given Convergence Rate". Hindawi Publishing Corporation Advances in Artificial Neural Systems (Hindawi),2013; Volume 2013, Article ID 908602, 5 pages

[7] Prionald Kornelius Effendi. Penerapan Backpropagation Untuk Peramalan Harga Kurs Valuta Asing (USD)". Universitas Putra Indonesia "YPTK" Padang;2013.

[8] Agus Nurkhozin, Irawan, M. I. and Mukhlas, I. Komparasi Hasil Klasifikasi Penyakit Diabetes Mellitus Menggunakan Jaringan Syaraf Tiruan Backpropagation dan Learning Vector Quantization. Prosiding Seminar Nasional Penelitian, Pendidikan dan Penerapan MIPA, Fakultas MIPA, Universitas Negeri Yogyakarta;2011.

[9] Umer, M.. F. and Khiyal. Classification of Textual Document Using Learning Vector Quantization. Information Technology Journal 6(1), Department of Computer Science, Internasional Islamic University, Islamabad, Pakistan;2007. ISSN 1812-5638, 154-159

[10] Anike, M., Sutoyo, dan Ernawati. Pengembangan Sistem Jaringan Syaraf Tiruan Dalam Memprediksi Jumlah Dokter Keluarga Menggunakan Backpropagation (Studi Kasus: Regional X Cabang Palu). Seminar Nasional Teknologi Informasi dan Komunikasi (SENTIKA);2012.ISSN: 2089-9815. 209-216.

[11] Mubiru, J. Using Artificial Neural Networks to Predict Direct Solar Irradiation. Hindawi Publishing Corporation Advances in Artificial Neural Systems. Volume 2011, Article ID 142054, 6 pages.

[12] Siang, J. J. Jaringan Syaraf Tiruan \& Pemogramannya Menggunakan Matlab. Edisi:2. Yogyakarta;2009. Andi Offset. Hal 2.

[13] Insania, N. Analisis Performansi Metode Jaringan Syaraf Tiruan Learning Vector Quantization Untuk Pendeteksian Anak Berbakat (Gifted Child) Pada Masa Perkembangan. Fakultas Teknik Dan Ilmu Komputer Universitas Komputer Indonesia; 2014.

[14] Kusumadewi, S. (2010). "Membangun Jaringan Syaraf Tiruan Dengan Matlab \& Excellink". Jogjakarta : Graha Ilmu. 